\title{
Metode Proyek dan Pengaruhnya Terhadap Kerjasama Anak Usia 5-6 Tahun di RA Al-Anshar Tanjung Pura
}

\author{
${ }^{1}$ Masganti Sit \\ Universitas Islam Negeri Sumatera Utara \\ email: masganti@uinsu.ac.id \\ ${ }^{2}$ Nurussakinah Daulay \\ Universitas Islam Negeri Sumatera Utara \\ email: daulayina@yahoo.co.id \\ ${ }^{3}$ Siti Fatmah Manik \\ Universitas Islam Negeri Sumatera Utara \\ email: siti.fatma9898@gmail.com
}

$\begin{array}{llll}\text { Article received } & : 15 \text { Februari } 2021 & \text { Review process } & : 16 \text { Februari } 2021 \\ \text { Article accepted } & : 1 \text { Maret } 2021 & \text { Article published } & : 8 \text { Maret } 2021\end{array}$

\begin{abstract}
Abstrak
Penelitian ini bertujuan untuk mengetahui pengaruh metode proyek terhadap kerjasama anak usia 5-6 tahun. Penelitian ini berjenis quasy experimental design tipe non equivalent control group sehingga sampel yang diteliti yaitu 24 orang anak usia 5-6 tahun di RA AlAnshar Tanjung Pura yang terdistribusi pada dua kelas. Kelas eksperimen menerapakn metode proyek dan kelas kontrol menerapkan metode demonstrasi (metode yang biasa digunakan di Al-Anshar Tanjung Pura). Instrumen penelitian yang digunakan yaitu lembar observasi dan rubrik penilaian kerjasama. Teknik analisis data pada penelitian ini menggunakan uji hipotesis dengan rumus uji-t. Hasil penelitian menunjukkan bahwa: (1) anak pada kelas eksperimen setelah menerapkan metode proyek mempunyai kriteria kerjasama berkembang sangat baik; (2) anak pada kelas kontrol setelah menerapkan metode demonstrasi seperti proses pembelajaran biasanya mempunyai kriteria kerjasama berkembang sesuai harapan; dan (3) terdapat pengaruh yang signifikan antara penggunaan metode proyek tehadaap kerjasama anak usia 5-6 tahun di RA Al-Anshar Tanjung Pura.

Kata kunci: Anak usia dini; Kerjasama; Metode proyek; Raudhatul athfal
\end{abstract}

\begin{abstract}
This study aims to determine the effect of project methods on cooperation between children aged 5-6 years. This research was a quasy experimental design type of non equivalent control group so that the sample studied was 24 children aged 5-6 years in RA Al-Anshar Tanjung Pura who were distributed in two classes. The experimental class applied the project method and the control class applied the demonstration method (a method commonly used in Al-Anshar Tanjung Pura). The research instruments used were the observation sheet and cooperation assessment rubric. The data analysis technique in this study used a hypothesis test with the t-test formula. The results showed that: (1) children in the experimental class after applying the project method had very good development cooperation criteria; (2) children in the control class after applying demonstration methods such as the learning process usually have the criteria for developing cooperation as expected; and (3) there is a significant influence between the use of the project method in the collaboration of children aged 5-6 years at RA Al-Anshar Tanjung Pura.
\end{abstract}

Keywords: Early childhood; Kerjasama; Project method; Raudhatul athfal 


\section{A. PENDAHULUAN}

Anak adalah generasi penerus bangsa yang kehadirannya ditunggu-tunggu. Pertumbuhan dan perkembangan anak sangat diperhatikan, dan pencapaian cita-citanya diharapkan agar menjadi insan yang berguna dalam keluarga, sekolah, masyarakat sekitar maupun secara kompleks. Anak usia dini adalah seorang pembelajar yang aktif. Sehingga pada saat bergerak, anak mencari rangsangan yang dapat meningkatkan kesempatannya untuk belajar. Anak pada usia 6 tahun emosinya tak stabil. Pada usia 5 tahun mereka akan memperlihatkan ketegangan dengan cara menimbulkan perselisihan, seperti: anak tidak mau belajar, membantah guru, dan mencari jati diri dari orang tuanya. Anak juga ingin mencari kehangatan dan keamanan. (Prastowo, 2018)

Aspek perkembangan yang begitu penting dikembangkan untuk anak usia dini merupakan aspek perkembangan sosial yaitu kerjasama. Kerjasama adalah sekumpulan anak belajar bermain atau dapat juga dikatakan bekerjasama dengan anak yang lainnya. Jadi makin banyaknya kesempatan melakukan kegiatan berkelompok, maka semakin cepat anak belajar melakukan kegiatannya dengan bekerjasama. (Susanto, 2015)

Menurut Elizabeth B. Hurlock dalam (Susanto, 2017) mengatakan bahwa kerjasama artinya anak dapat bekerjasama dengan orang lain, seperti anak ikut terlibat dalam kegiatan dengan temannya, anak juga mengajak temannya untuk bermain bersama, anak juga mengikuti permainan yang lain dan anak juga saling membantu dalam menyelesaikan tugasnya dengan berkelompok.

Berdasarkan dari hasil pengamatan awal yang telah dilakukan di RA Al-Anshar Tanjung Pura bahwa fenomena yang berhasil peneliti dapatkan di lapangan yaitu ada anak yang terlihat lebih mementingkan dirinya sendiri, dan anak belum dapat bekerjasama dengan temannya dalam menyelesaikan tugasnya, anak juga tidak mau meminjamkan mainannya pada temannya dan juga anak lebih memilih menghabiskan waktunya untuk bermain sendiri seperti anak lebih memilih mewarnai buku gambarnya sendiri, bermain puzzle sendiri. Kondisi tersebut disebabkan karena pembelajarannya yang lebih berpusat pada guru, dalam melaksanakan pembelajarannya anak juga jarang diberikan kesempatan untuk mengerjakan kegiatan ataupun tugas secara berkelompok. Hal ini yang harus 
http://jurnaltarbiyah.uinsu.ac.id/index.php/raudhah

e-mail: jurnalraudhah@uinsu.ac.id

p-ISSN: 2338-2163

e-ISSN: $2716-2435$

diperbaiki saat melakukan kegiatan pembelajaran. Salah satunya metode yang dapat dilakukan dalam kegiatan pembelajaran di RA Al-Anshar Tanjung Pura yaitu dengan menggunakan metode yang melibatkan anak untuk melakukan kegiatan bersama, bersosialisasi, toleransi dan dapat mengungkapkan pendapatnya dengan baik yaitu dengan menerapkan metode proyek. Metode proyek merupakan suatu cara dengan pemberian pengalaman belajar anak yang mempertemukan pada persoalan sehari-hari dapat dipecahkan secara bersama-sama.

Berdasarkan pengamatan yang telah dilakukan oleh Ni Wayan Eka Praba Dewi (2018) bahwa proses pembelajaran yang sering diberikan kegiatan secara individu seperti: memberikan lembar kerja yang dikerjakan secara individu, bercakap- cakap, menebak flash card secara bergilir dan tanya jawab sehingga anak kurang tertarik dengan pembelajaran tersebut. Karena anak merasa bosan maka hal itu membuat anak terkadang tidak mau menyelesaikan lembar kerja yang diberikan oleh gurunya dan anak akan mencari kesibukannya sendiri. Kegiatan belajar yang diberikan secara individu tidak memberikan kesempatan pada anak untuk lebih berinteraksi dengan temannya, menyelesaikan tugas dengan kerjasama, bekerja dalam tim serta bermain dengan anak yang lainnya.

Hal ini sejalan dengan pengamatan yang dilakukan St Seni Lestari (2016) perilaku anak masih belum mampu bekerjasama, masih tidak mau bermain dengan temantemannya, serta masih belum dapat menunjukkan sikap perduli pada temannya. Anak sulit untuk berbagi mainan dan anak lebih memilih berebut. Saling menyerang dan berkelahi juga terjadi saat berlangsungnya kegiatan di kelas, maka dapat disimpulkan bahwa anak masih kesulitan dalam bekerjasama. Hasil observasi tersebut menunjukkan perlunya dilakukan upaya penerapan pembelajaran yang inovatif dalam meningkatkan kerjasama anak.

Metode berperan penting pada suatu kegiatan belajar dan juga menjadi bagian dari strategi pembelajaran. Metode adalah rancangan yang telah disusun dengan suatu aktivitas nyata agar tercapainya tujuan tersebut dengan maksimal. Sesuai dari tujuan dan juga program kegiatan, metode dipakai dalam pembelajaran sangat berkaitan dengan perkembangannya kognitif, motorik, kreativitas, emosi, bahasa sosial maupun seni. 
Metode Proyek adalah suatu pengalaman belajar anak yang diberikan dengan menghadapkan kegiatan sehari- hari yang dapat didiskusikan bersama-sama. Metode proyek ini dalam penggunaannya tidak sesuai dengan pemahaman dari pemecahan masalah yang tidak bisa selesai apabila dibahas dari segala sisi. Pemecahan masalah ini tidak hanya satu mata pelajaran, melainkan berbagai mata pelajaran yang berkaitan sehingga dalam masalah dapat dipecahkan secara keseluruhannya. Salah satu metode dapat mengembangkan kerjasama anak yaitu dengan menggunakan metode proyek. Nurlaily mengatakan bahwa metode proyek ini memberikan kesempatan pada anak agar meningkatkan keterampilannya yang telah dimiliki secara perorang maupun bersamasama dan juga dapat menimbulkan minat pada anak serta tanggung jawab pada tujuan keberhasilan suatu kelompok dan memiliki pemahaman yang utuh mengenai adanya suatu konsep tersebut.

Metode proyek ini memiliki keistimewaannya sendiri, yaitu memungkinkan setiap peserta didik untuk memperluas suatu wawasan pengetahuannya dibidang pelajaran tertentu, sehingga memungkinkan tersalurkannya minat anak, anak juga dilatih menelaah dan melihat suatu materi pembelajaran dalam konteks yang luas. Pada metode proyek ini adalah prinsipnya membahas bagaimana suatu tema yang melihat berbagai bidang studi sehingga terbentuklah kaitan yang logis antara bahasan pokok sebagai bidang pelajaran.

Dari permasalahan ini peneliti sangatlah penting untuk meneliti lebih lanjut yaitu dengan mengangkat judul "Pengaruh Penggunaan Metode Proyek Terhadap Kerjasama Anak Usia 5-6 Tahun di RA Al-Anshar Tanjung Pura Tahun 2020/ 2021”.

\section{B. METODE PENELITIAN}

Penelitian ini dilaksanakan di RA Al-Anshar Tanjung Pura yang beralamat di Jalan Jendral Sudirman, Pekan Tanjung Pura, Kabupaten Langkat pada semester genap tahun pelajaran 2020/2021. Penelitian ini berjenis kuantitatif eksperimen menggunakan quasy experimental design tipe non equivalent control group. Desain penelitian dicantumkan pada tabel 1: 
Tabel 1. Desain Eksperimen dan Kontrol

\begin{tabular}{|c|c|c|c|}
\hline Kelas & Pretes & Treatment & Postes \\
\hline Eksperimen & $\mathrm{O}_{1}$ & $\mathrm{X}$ & $\mathrm{O}_{2}$ \\
\hline Kontrol & $\mathrm{O}_{3}$ & - & $\mathrm{O}_{4}$ \\
\hline
\end{tabular}

Keterangan:

$\mathrm{O}_{1}$ : Observasi awal kegiatan menggunakan metode proyek.

$\mathrm{O}_{2}$ : Observasi setelah melakukan kegiatan menggunakan metode proyek.

$\mathrm{X}$ : Kelas eksperimen yang telah diberi perlakuan menggunakan metode proyek.

$\mathrm{O}_{3}$ : Observasi awal kegiatan menggunakan metode demonstrasi.

$\mathrm{O}_{4}$ : Observasi setelah melakukan kegiatan menggunakan metode demonstrasi.

(-) : Kelas kontrol yang telah diberi perlakuan menggunakan metode demonstrasi.

Tabel 1 menunjukkan bahwa penelitian ini menggunakan dua kelas, yaitu kelas eksperimen yang menerapkan metode proyek dan kelas kontrol yang menerapkan metode demonstrasi. Metode demonstrasi diterapkan pada kelas kontrol karena metode tersebut biasa digunakan di RA Al-Anshar Tanjung Pura. Populasi pada penelitian ini yaitu seluruh anak usia 5-6 tahun sebanyak 24 orang yang terdistribusi pada dua kelas. Sehingga teknik sampling yang digunakan pada penelitian ini yakni boring sampling. Menurut (Maisarah, 2019a; Sugiyono, 2017) boring/ total sampling adalah penentuan sampel dengan mengambil seluruh anggota populasi menjadi sampel penelitian. Dengan demikian, sampel pada penelitian ini juga sebanyak 24 orang anak usia 5-6 tahun. Pada penelitian ini menggunakan instrumen observasi dan rubrik penilaian untuk mengukur kerjasama anak yang terdiri dari beberapa capaian indikator pada tabel 2:

Tabel 2. Capaian Indikator dari Kerjasama Anak Usia 5-6 Tahun

\begin{tabular}{|c|l|l|c|}
\hline No. & \multicolumn{1}{|c|}{ Indikator } & \multicolumn{1}{|c|}{ Capaian Indikator } & Jumlah \\
\hline 1 & $\begin{array}{l}\text { Ikut terlibat dalam kegiatan } \\
\text { teman. }\end{array}$ & $\begin{array}{l}\text { Anak ikut serta berkumpul dalam kegiatan } \\
\text { berkelompok. }\end{array}$ & 2 \\
\cline { 3 - 4 } & & Anak menyesuaikan diri dengan teman. & 2 \\
\hline 2 & Berbagi tugas dalam & Anak membantu teman merapikan alat & \\
\hline
\end{tabular}


http://jurnaltarbiyah.uinsu.ac.id/index.php/raudhah

e-mail: jurnalraudhah@uinsu.ac.id

p-ISSN: 2338-2163

e-ISSN: 2716-2435

\begin{tabular}{|c|c|c|c|}
\hline No. & Indikator & Capaian Indikator & Jumlah \\
\hline & \multirow{2}{*}{$\begin{array}{l}\text { melakukan kegiatan dengan } \\
\text { teman. }\end{array}$} & permainan yang telah digunakan. & \\
\hline & & Anak berbagi bahan kegiatan dengan teman. & \\
\hline \multirow[t]{2}{*}{3} & \multirow{2}{*}{$\begin{array}{l}\text { Mengajak teman bermain } \\
\text { bersama dalam permainan. }\end{array}$} & Anak mengajak teman untuk bermain bersama. & \multirow[t]{2}{*}{2} \\
\hline & & Anak berkomunikasi dengan teman yang lain. & \\
\hline \multirow[t]{2}{*}{4} & \multirow{2}{*}{$\begin{array}{l}\text { Mengikuti permainan teman } \\
\text { yang lain. }\end{array}$} & Anak mengikuti aturan main dalam kelompok. & \multirow[t]{2}{*}{2} \\
\hline & & $\begin{array}{l}\text { Anak mengikuti pembagian tugas dalam } \\
\text { permainan. }\end{array}$ & \\
\hline \multirow[t]{2}{*}{5} & \multirow{2}{*}{$\begin{array}{l}\text { Saling membantu dalam } \\
\text { menyelesaikan tugas } \\
\text { kelompok. }\end{array}$} & Anak menolong temannya yang kesusahan. & \multirow[t]{2}{*}{2} \\
\hline & & Anak memberitahu teman yang tidak mengerti. & \\
\hline \multicolumn{3}{|r|}{ Total } & 10 \\
\hline
\end{tabular}

Data pada tabel 2 yang diperoleh dari instrumen penelitian kemudian dianalisis menggunakan uji hipotesis komparatif dengan rumus uji-t data homogen sebagai berikut:

$$
t_{\text {hitung }}=\frac{\bar{x}_{1}-\bar{x}_{2}}{\sigma^{2} \sqrt{\frac{1}{n_{1}}+\frac{1}{n_{2}}}}(\text { Jaya, 2018; Maisarah, 2019b; Rosyadi, 2018) }
$$

Keterangan :

t : koefisien t-test

$\sigma^{2} \quad$ : koefisien varians

$\bar{x}_{1} \quad$ : nilai rata-rata kelompok 1

$\bar{x}_{2}:$ nilai rata-rata kelompok 2

$\mathrm{n}_{1} \quad$ : banyak data kelompok 1

$\mathrm{n}_{2} \quad$ : banyak data kelompok 2

Kriteria pengujian hipotesis adalah:

Jika $t_{\text {hitung }}<\mathrm{t}_{\text {tabel }}$ maka $\mathrm{H}_{0}$ diterima dan $\mathrm{H}_{\mathrm{a}}$ ditolak.

Jika $t_{\text {hitung }}>\mathrm{t}_{\text {tabel }}$ maka $\mathrm{H}_{0}$ ditolak dan $\mathrm{H}_{\mathrm{a}}$ diterima 
http://jurnaltarbiyah.uinsu.ac.id/index.php/raudhah

e-mail: jurnalraudhah@uinsu.ac.id

p-ISSN: 2338-2163

e-ISSN: 2716-2435

\section{HASIL DAN PEMBAHASAN}

1. Data Nilai Pretes Kerjasama Anak Pada Kelas Eksperimen dan Kelas Kontrol

Data nilai pretes kerjasama anak di kelas eksperimen dan kontrol tersaji pada tabel 3:

Tabel 3. Data Pretes Kelas Eksperimen dan Kelas Kontrol

\begin{tabular}{|c|c|c|c|}
\hline No & Statistik & Kelas Eksperimen & Kelas Kontrol \\
\hline 1. & Rata-rata & 24,6 & 21,7 \\
\hline 2. & Simpangan Baku & 2,14 & 1,81 \\
\hline 3. & Varians & 4,60 & 3,29 \\
\hline 4. & Maksimum & 28 & 25 \\
\hline 5. & Minimum & 21 & 19 \\
\hline
\end{tabular}

Tabel 3 membuktikan bahwa nilai pretes di kelas eksperimen maupun kelas kontrol tidak jauh berbeda. Rata-rata nilai pretes di kelas eksperimen yaitu 24,6 sedangkan di kelas kontrol yaitu 21,7, keduanya mempunyai selisih nilai sebesar 2,9. Nilai tertinggi yang diperoleh anak di kelas eksperimen yaitu 28, di kelas kontrol yaitu 25, dan nilai tertinggi jika semua indikator tercapai berkembang sangat baik (BSB) yaitu 40. Nilai terendah yang diperoleh anak di kelas eksperimen yaitu 21, di kelas kontrol yaitu 19, dan nilai terendah jika semua indikator tercapai belum berkembang (BB) yaitu 10. Kriteria tingkat kerjasama anak dilihat dari rata-rata nilai pretes maka diperoleh bahwa di kelas eksperimen sama dengan kelas kontrol yaitu mulai berkembang (MB).

\section{Data Nilai Postes Kerjasama Anak Pada Kelas Eksperimen dan Kontrol}

Data nilai postes kerjasama anak di kelas eksperimen dan kontrol tersaji pada tabel 4:

Tabel 4. Data postes Kelas Eksperimen dan Kelas Kontrol

\begin{tabular}{|c|c|c|c|}
\hline No & Statistik & Kelas Eksperimen & Kelas Kontrol \\
\hline 1. & Rata-rata & 36,6 & 32,8 \\
\hline 2. & Simpangan Baku & 1,15 & 1,58 \\
\hline 3. & Varians & 1,33 & 2,51 \\
\hline 4. & Maksimum & 38 & 35 \\
\hline 5. & Minimum & 35 & 30 \\
\hline
\end{tabular}


Tabel 4 membuktikan bahwa nilai postes di kelas eksperimen maupun kelas kontrol mempunyai perbedaan. Rata-rata nilai postes di kelas eksperimen yaitu 36,6 sedangkan di kelas kontrol yaitu 32,8, keduanya mempunyai selisih nilai sebesar 3,8. Nilai tertinggi yang diperoleh anak di kelas eksperimen yaitu 38, di kelas kontrol yaitu 35, dan nilai tertinggi jika semua indikator tercapai berkembang sangat baik (BSB) yaitu 40. Nilai terendah yang diperoleh anak di kelas eksperimen yaitu 35, di kelas kontrol yaitu 30, dan nilai terendah jika semua indikator tercapai belum berkembang (BB) yaitu 10. Hal tersebut menunjukkan bahwa nilai tertinggi di kelas eksperimen merupakan nilai terendah di kelas kontrol, sehingga disimpulkan bahwa kerjasama anak di kelas eksperimen mempunyai nilai yang lebih tinggi dibandingkan kelas kontrol. Dari kriteria tingkat kerjasama anak juga diperoleh bahwa anak di kelas eksperimen mempunyai kategori berkembang sangat baik (BSB) sedangkan di kelas kontrol mempunyai kategori 1 tingkat di bawahnya yaitu berkembang sesuai harapan $(\mathrm{BSH})$.

Tabel 5. Nilai Rata-rata Kerjasama Anak Pada Saat Pretes dan Postes

\begin{tabular}{|c|c|c|c|c|}
\hline \multirow{2}{*}{ Keterangan } & \multicolumn{2}{|c|}{ Kelas Eksperimen } & \multicolumn{2}{c|}{ Kelas Kontrol } \\
\cline { 2 - 5 } & Pretes & Postes & Pretes & Postes \\
\hline Jumlah Nilai & 296 & 440 & 261 & 394 \\
\hline Rata-rata & 24,6 & 36,6 & 21,7 & 32,8 \\
\hline
\end{tabular}

Setelah pretes dan postes dilaksanakan di kedua kelas, maka akan dilakukan pengujian persyaratan analisis yaitu uji kesamaan dengan menggunakan uji t dengan syarat data harus normal dan homogen. Berikut ini akan dijelaskan uji normalitas, uji homogenitas dan uji hipotesis dari kedua sampel yaitu kelas eksperimen dan kelas kontrol. Uji normalitas dengan menggunakan uji liliefors yang bertujuan agar mengetahui apakah penyebaran data dari hasil penelitian memiliki sebaran data yang berdistribusi normal atau tidak. Sampel yang berdistribusi normal jika dipenuhi syarat $\mathrm{L}_{0}<\mathrm{L}_{\text {tabel }} \alpha=0,05$. Uji normalitas pretes pada kelas eksperimen diperoleh 0,128 dan data pretes kelas kontrol diperoleh 0,088 dan data dari postes kerjasama anak pada kelas eksperimen diperoleh 0,197 dan data postes kerjasama anak pada kelas kontrol diperoleh 0125. Jadi dapat 
http://jurnaltarbiyah.uinsu.ac.id/index.php/raudhah

e-mail: jurnalraudhah@uinsu.ac.id

p-ISSN: 2338-2163

e-ISSN: 2716-2435

disimpulkan bahwa data pretes dan postes kerjasama anak di kelas eksperimen dan kelas kontrol mempunyai distribusi yang normal.

Pengujian homogenitas data untuk mengetahui apakah sampel yang akan digunakan dalam penelitian berasal dari populasi yang homogen atau tidak. Untuk pengujian homogenitas digunakan uji kesamaan kedua varians yaitu uji F. Jika $F_{\text {hitung }}>F_{\text {tabel }}$ maka $\mathrm{H}_{0}$ ditolak dan jika $F_{\text {hitung }}<\mathrm{F}_{\text {tabel }}$ maka $\mathrm{H}_{0}$ diterima. Dengan derajat kebebasan pembilang $=\left(\mathrm{n}_{1^{-}}\right.$ 1) dan derajat kebebasan penyebut $=\left(n_{2}-1\right)$ dengan taraf nyata $\alpha=0,05$.

Tabel 6. Data Hasil Uji Homogenitas Kerjasama Anak

\begin{tabular}{|l|l|l|l|l|l|}
\hline Data & Varians Terbesar & Varians Terkecil & $\mathrm{F}_{\text {hitung }}$ & $\mathrm{F}_{\text {tabel }}$ & Keterangan \\
\hline Pretes & 4,60 & 3,29 & 1,39 & 2,82 & Homogen \\
\hline Postes & 2,51 & 1,33 & 1,89 & 2,82 & Homogen \\
\hline
\end{tabular}

Tabel 6 menunjukkan bahwa hasil dari hitungan antara Pretes pada kelas eksperimen dan kelas kontrol yang didapat adalah $\mathrm{F}_{\text {hitung }}=1,39$ dan $\mathrm{F}_{\text {tabel }}=2,82$ dengan kriteria $\alpha=$ 0,05. Karena $F_{\text {hitung }}<F_{\text {tabel }}$ maka data nilai Pretes pada kelas eksperimen dan kontrol dinyatakan homogen. Begitu juga hitungan antara Postes pada kelas eksperimen dan kelas kontrol didapat $F_{\text {hitung }}=1,89$ dan $F_{\text {tabel }}=2,82$. Karena $F_{\text {hitung }}<F_{\text {tabel }}$ maka data nilai Postes kelas eksperimen dan kelas kontrol dinyatakan homogen.

Setelah diketahui bahwa kelas eksperimen dan kelas kontrol berdistribusi normal dan homogen, maka akan dilanjutkan dengan melakukan pengujian hipotesis dalam penelitian ini menggunakan uji t. Pengujian hipotesis ini dilakukan dengan uji satu pihak sehingga kriteria untuk menerima ataupun menolak $\mathrm{H}_{\mathrm{o}}$ ialah jika $\mathrm{F}_{\text {hitung }}>\mathrm{F}_{\text {tabel }}$ pada taraf nyata $\alpha=$ 0,05. $\mathrm{H}_{\mathrm{a}}$ diterima dan $\mathrm{H}_{\mathrm{o}}$ ditolak.

\section{Pengaruh Metode Proyek Terhadap Kerjasama Anak Usia 5-6 Tahun di RA Al-}

\section{Anshar Tanjung Pura}

Dari hasil analisis data membuktikan bahwa terdapat perbedaan yang signifikan terhadap kerjasama anak yang mengikuti penerapan metode proyek. Hal ini ditunjukkan pada hasil analisis data dengan menggunakan uji-t, diketahui nilai kelas eksperimen yang memperoleh nilai $\mathrm{t}_{\text {hitung }}=24,691$ dengan taraf $\alpha=0,050$ didapat tabel $\mathrm{t}$ pada $\mathrm{dk} 10$ 
http://jurnaltarbiyah.uinsu.ac.id/index.php/raudhah

e-mail: jurnalraudhah@uinsu.ac.id

p-ISSN: 2338-2163

e-ISSN: 2716-2435

diperoleh nilai $t_{\text {tabel }} 2,228$. Hasil perhitungan tersebut menunjukkan bahwa $t_{\text {hitung }}>t_{\text {tabel }}$ sehingga hasil penelitian ini adalah signifikan.

Tabel 7. Data Hasil Perhitungan Uji Hipotesis

\begin{tabular}{|c|c|c|c|l|}
\hline No. & Uji Hipotesis & $\mathbf{t}_{\text {hitung }}$ & $\mathbf{t}_{\text {tabel }}$ & Kesimpulan \\
\hline 1. & Kelas Eksperimen & 24,691 & 2,228 & $\mathrm{t}_{\text {hitung }}>\mathrm{t}_{\text {tabel }}$ \\
\hline 2. & Kelas Kontrol & 10,48 & 2,228 & $\mathrm{t}_{\text {hitung }}>\mathrm{t}_{\text {tabel }}$ \\
\hline
\end{tabular}

Sedangkan hasil analisis data dengan menggunakan uji-t, diketahui nilai postes dari kelas eksperimen dan kelas kontrol dengan nilai $t_{\text {hitung }}=4,458$ dengan taraf $\alpha=0,05$. didapat tabel $\mathrm{t}$ pada $\mathrm{dt}$ diperoleh nilai $\mathrm{t}_{\text {tabel }}=2,228$. Hasil perhitungan stersebut menunjukkan bahwa $t_{\text {hitung }}>t_{\text {tabel }}$ sehingga hasil penelitian ini adalah siginifikan. Berikut ini disajikan dalam bentuk tabel hasil perhitungan uji hipotesis nilai posttest kelas eksperimen dan kelas kontrol.

Tabel 8. Hasil Uji Hipotesis Nilai Postes Kelas Eksperimen dan Kelas Kontrol

\begin{tabular}{|c|c|c|c|l|l|}
\hline \multicolumn{2}{|c|}{ Skor rata-rata nilai postes } & \multirow{2}{*}{$\mathbf{k}$} & $\mathbf{t}_{\text {hitung }}$ & $\mathbf{t}_{\text {tabel }}$ & Kesimpulan \\
\cline { 1 - 2 } Eksperimen & Kontrol & & & & \\
\hline 36,6 & 32,8 & 10 & 4,458 & 2,228 & $t_{\text {hitung }}>t_{\text {tabel }}$ \\
\hline
\end{tabular}

Hal ini didasari pada rata-rata skor hasil sikap kerjasama anak. Rata-rata nilai postes anak yang belajar menggunakan metode proyek adalah 36,6 yang berada pada kategori tinggi sedangkan nilai rata-rata postes sikap kerjasama anak yang belajar dengan metode demonstrasi adalah 32,8. Perbedaan nilai rata-rata antara kelas eksperimen dengan kelas kontrol dapat diketahui bahwa sekitar 3,8\% perbedaan pengaruh metode proyek dengan metode demonstrasi terhadap kerjasama anak.

Sesuai dengan tujuan penelitian ini yaitu untuk mengetahui adanya pengaruh metode proyek terhadap kerjasama anak usia 5-6 Tahun di RA Al-Anshar Tanjung Pura, maka dilakukan penelitian sebanyak 6 kali pertemuan sebelum dan sesudah perlakuan (pretes dan postes) dilakukan dengan observasi anak. Mengumpulkan data penelitian dengan instrumen yang telah disediakan. Dari hasil observasi kedua sampel tersebut diperoleh hasil yaitu 
http://jurnaltarbiyah.uinsu.ac.id/index.php/raudhah

e-mail: jurnalraudhah@uinsu.ac.id

p-ISSN: 2338-2163

e-ISSN: 2716-2435

sebelum pemberian perlakuan, anak diberikan tes kemampuan awal sehingga diperoleh rata-rata nilai untuk kelas eksperimen sebesar 24,66 dan untuk kelas kontrol sebesar 21,75.

Hasil ini menunjukkan bahwa nilai rata-rata kedua kelas tersebut hampir sama. Tetapi nilai tersebut masih tergolong rendah. Oleh karena itu kedua kelas tersebut perlu diberikan perlakuan. Setelah diberikan perlakuan pada kelas eksperimen dan kelas kontrol tersebut maka diperoleh nilai rata-rata dari kelas eksperimen menggunakan metode proyek 36,66 dan kelas kontrol dengan metode demonstrasi 32,83 . Jadi terlihat bahwa kerjasama anak pada dua kelas yang berbeda nilai rata-ratanya berbeda, dimana rata-rata kerjasama anak di kelas eksperimen lebih tinggi daripada rata-rata kerjasama anak di kelas kontrol. Berdasarkan data nilai pos-test anak ditemukan bahwa terdapat pengaruh yang signifikan antara metode proyek terhadap kerjasama anak hal ini terlihat dari nilai rata-rata kerjasama anak sebelum dan sesudah diberi perlakuan adalah 24,66 menjadi 36,66.

Hal ini juga dibuktikan dari hasil pengujian hipotesis dimana $t_{\text {hitung }}>t_{\text {tabel }}$ yaitu 24,691 $>$ 2,228 dengan observasi anak. Pemilihan sebuah metode dalam pembelajaran merupakan hal yang sangat penting dalam proses kegiatan belajar mengajar disekolah. Untuk dapat memaksimalkan proses pembelajaran maka guru harus pandai dalam memilih metode yang tepat, salah satu metode yang dapat mengembangkan kerjasama anak adalah metode proyek.

Proyek adalah salah satu bentuk pemecahan masalah, tetapi kegiatan memecahkan masalah tidak hanya dilakukan sendiri karena kerja mandiri anak juga dapat dilakukan dengan memadukan kegiatan kerja anak yang lain yang terlibat dalam proyek. Indikator yang digunakan sebagai acuan peneliti untuk mendapatkan data-data agar mencapai kesimpulan adalah ikut terlibat dalam kegiatan teman, berbagi tugas dalam melakukan kegiatan dengan teman, mengajak teman untuk bermain bersama dalam suatu permainan, mengikuti permainan teman yang lain, dan saling membantu dalam menyelesaikan tugas kelompok. Menurut (Moeslichatoen, 2004) metode proyek dapat dimanfaatkan untuk mengembangkan sikap kerjasama dan interaksi sosial di antara anak yang lain.

Pendapat dari (Basrowi, 2012) menyatakan bahwa kerjasama adalah suatu bentuk proses sosial didalamnya terdapat aktifitas tertentu yang ditujukan untuk mencapai suatu tujuan bersama dengan saling membantu dan saling memahami aktivitasnya masing- 
http://jurnaltarbiyah.uinsu.ac.id/index.php/raudhah

e-mail: jurnalraudhah@uinsu.ac.id

p-ISSN: 2338-2163

e-ISSN: $2716-2435$

masing. Anak masing-masing belajar tanggung jawab terhadap pekerjaannya dengan kesepakatannya. Kemudian (Ahmadi, 2003) mengemukakan bahwa terbentuknya suatu sikap dipengaruhi oleh keluarganya, sekolah, agama dan adat istiadat. Dalam hal ini lingkungan sekolahlah dapat membantu terbentuknya kerjasama anak karena didalam pembelajaran kelas guru membentuk kelompok belajar agar anak dapat belajar mengembangkan keterampilan sosialnya, tidak hanya kerjasama yang anak akan berkembang tetapi keterampilansosial anak yang lain juga akan ikut berkembang misalnya anak saling membantu dan menolong antar individu yang sedang mengerjakan tugas dan anak juga mau berbagi dengan teman-teman yang lain.

Hasil penelitian lain yang dilakukan oleh (Nurhalimah, 2012) menunjukkan bahwa Hasil $\mathrm{t}$-tes diperoleh nilai $\mathrm{t}$ hitung $\leq-\mathrm{t}$ tabel yaitu $-25.062 \leq-1.699$ dengan probabilitas sebesar $0.00000000000000000000335<\alpha=0,05$ maka Ho ditolak yang berarti terdapat pengaruh metode proyek terhadap kemampuan kerjasama anak usia dini kelompok B di RA Perwanida 03 Mojo Andong Boyolali Tahun Pelajaran 2011/2012. Penelitian yang dilakukan (Gucha, 2016) menunjukkan bahwa hasil penelitian kemampuan kerjasama pada anak meningkat setelah dilakukan metode proyek terlihat adanya peningkatan kemampuan kerjasama pada anak sebesar 52,35. Penelitian lain yang dilakukan oleh (Dewi, 2018) membuktikan bahwa ada pengaruh metode pembelajaran berbasis proyek terhadap kemampuan kerjasama anak dengan $\mathrm{t}=21,551$, $\mathrm{sig}=0.000$. Berdasarkan analisis perhitungan statistik melalui taraf signifikan $5 \%$ terlihat dari $t_{\text {hitung }}$ lebih besar dari $t_{\text {tabel }}$ maka hipotesis alternatif (ha) diterima, artinya metode proyek berpengaruh dalam meningkatkan kemampuan kerjasama pada anak B di TK Al-Wafa'a Ombilin.

\section{SIMPULAN DAN SARAN}

Beberapa simpulan yang diperoleh dari penelitian ini yaitu: (1) anak pada kelas eksperimen setelah menerapkan metode proyek mempunyai kriteria kerjasama berkembang sangat baik; (2) anak pada kelas kontrol setelah menerapkan metode demonstrasi seperti proses pembelajaran biasanya mempunyai kriteria kerjasama berkembang sesuai harapan; dan (3) terdapat pengaruh yang signifikan antara penggunaan metode proyek tehadaap kerjasama anak usia 5-6 tahun di RA Al-Anshar Tanjung Pura. 
http://jurnaltarbiyah.uinsu.ac.id/index.php/raudhah

e-mail: jurnalraudhah@uinsu.ac.id

p-ISSN: 2338-2163

e-ISSN: $2716-2435$

Penelitian ini mengajukan beberapa saran yang ditujukan kepada berbagai pihak berkepentingan dengan hasil penelitian, diantaranya yaitu: (1) Bagi anak, anak hendaknya diberi kesempatan untuk terlibat langsung dalam pembelajaran dengan menggunakan metode proyek, sehingga dapat mengembangkan kerjasama anak; (2) Bagi guru, diharapkan agar metode proyek ini dapat digunakan sebagai salah satu alternatif metode dalam pembelajaran; dan (3) Bagi sekolah, hendaknya memfasilitasi dalam proses belajar mengajar guru dalam penyediaan alat dan bahan untuk kegiatan pembelajaran.

\section{DAFTAR PUSTAKA}

Ahmadi, A. (2003). Psikologi Sosial. Jakarta: Rineka Cipta.

Basrowi. (2012). Sosiologi Politik. Jakarta: Ghalia Indonesia.

Dewi, N. W. E. P. (2018). Pengaruh Metode Pembelajaran Berbasis Proyek Terhadap Kemampuan Kerjasama Pada Anak Kelompok B Taman Kanak-kanak. Jurnal Pendidikan, 6(3).

Gucha, F. P. (2016). Pengaruh Metode Proyek Terhadap Kemampuan Kerjasama Anak Usia Dini Kelompok B-1 di TK Al-Wafa'a Ombilin. IAIN Batusangkar.

Jaya, I. (2018). Penerapan Statistik Untuk Pendidikan. Medan: Perdana Publishing.

Maisarah. (2019a). Metodologi Penelitian Pendidikan Pendekatan Kuantitatif. Medan: Akasha Sakti.

Maisarah. (2019b). Statistik Pendidikan. Medan: Akasha Sakti.

Moeslichatoen, R. (2004). Metode Pengajaran di Taman Kanak-Kanak. Jakarta: Rineka Cipta.

Nurhalimah, V. (2012). Pengaruh Metode Proyek Terhadap Kemampuan Kerjasama Anak Usia Dini Kelompok B Di RA Perwanida 03 Mojo Adong Boyolali. Universitas Muhamadiyah Surakarta.

Prastowo, A. (2018). Sumber Belajar dan Pusat Sumber Belajar Teori \& Aplikasinya di Sekolah. In Depok: Kencana.

Rosyadi, A. A. P. (2018). Statistika Pendidikan. In Universitas Muhammadiyah Malang. Unimed Press. 
http://jurnaltarbiyah.uinsu.ac.id/index.php/raudhah

e-mail: jurnalraudhah@uinsu.ac.id

p-ISSN: 2338-2163

e-ISSN: $2716-2435$

Sugiyono. (2017). Metode Penelitian Pendidikan Pendekatan Kuantitatif, Kualitattif dan RnD. Bandung: Alfabeta.

Susanto, A. (2015). Bimbingan \& Konseling di Taman Kanak- Kanak. Jakarta: Prenadamedia Group.

Susanto, A. (2017). Pendidikan Anak Usia Dini (Konsep dan Teori). Jakarta: Bumi Aksara. 